\title{
SURVEY OF PRESENCE OF NON-INDIGENOUS EURYTEMORA CAROLLEEAE IN THE GULF OF RIGA (BALTIC SEA) FIVE YEARS AFTER ITS FIRST DISCOVERY
}

\author{
Labuce Astra ${ }^{1, \#}$, Ikauniece Anda ${ }^{1}$, Strāḳe Solvita ${ }^{1}$, and Souissi Anissa ${ }^{2}$ \\ ${ }^{1}$ Latvian Institute of Aquatic Ecology, 4 Voleru Str., Rīga, LV-1007, LATVIA \\ 2 Univ. Lille 1 CNRS, Univ. Littoral Cote d'Opale, UMR 8187, LOG, Laboratoire d'Océanologie et de Géosciences, \\ F 62930, Wimereux, FRANCE \\ \# Corresponding author, astra.labuce@ Ihei.lv
}

Communicated by Arvīds Barševskis

\begin{abstract}
In the brackish ecosystem of the Gulf of Riga, the calanoid copepod Eurytemora affinis is a key species, but recently a new non-indigenous species Eurytemora carolleeae was discovered in the region. In the present study, we aimed to validate the presence of $\mathrm{E}$. carolleeae in the southern part of the Gulf of Riga five years after its first discovery. The study area is the closest region to the Riga harbour - the main source of non-indigenous species arrival in the Gulf. Recent studies have predicted the possible potential of $\mathrm{E}$. carolleeae invasion due to its physiological plasticity. Male and female specimens of Eurytemora were collected in spring, summer, and autumn of 2013, and analysed based on three morphological indicators. Despite the higher reproduction rate of $\mathrm{E}$. carolleeae, this intrusive species does not seem to have succeeded in establishing during the five-year period after its first discovery in the Gulf of Riga, and hence does not present a threat to the native $\mathrm{E}$. affinis population in the study area.
\end{abstract}

Key words: zooplankton, calanoid copepod, brackish, invasion.

\section{INTRODUCTION}

Eurytemora affinis (Poppe, 1880) is a true estuarine calanoid copepod that inhabits brackish and fresh-waterbodies all over the northern hemisphere (e.g., Croskery, 1978; Lee and Frost, 2002). It has been described as a complex of cryptic species, because E. affinis populations are genetically highly divergent, though with similar morphological characteristics (Lee, 2000; Lee and Frost, 2002; Winkler et al., 2011; Sukhikh et al., 2016). Recent subsequent studies (Alekseev and Souissi, 2011; Sukhikh and Alekseev, 2013) distinguished two separate species within the complex of $E$. affinis, which launched a debate about if E. affinis is really a complex of cryptic or pseudocryptic species (Lajus et al., 2015). However, the present study refers to the native population of the Baltic Sea as E. affinis, instead of as a species complex, for the sake of convenience.

Eurytemora affinis is a dominating estuarine copepod in the Baltic Sea (Telesh and Heerkloss, 2004) and a key species in our study area - the Gulf of Riga (Ojaveer et al., 1998; Kornilovs et al., 2004). It is the main food source for the local herring (Anonymous, 2013; Livdāne et al., 2016) and one of the most abundant calanoid copepods controlling phytoplankton biomass during summer (Jurgensone et al., 2011). A recent study by Sukhikh et al. (2013) revealed the presence of Eurytemora carolleeae Alekseev and Souissi, 2011 in several sites of the Baltic Sea, including in the Gulf of Riga. Eurytemora carolleeae is a newly described species within the Eurytemora affinis complex (Alekseev and Souissi, 2011). Its invasion source was presumably from the eastern coast of North America where it is one of dominant estuarine copepods (Alekseev and Souissi, 2011). Eurytemora carolleeae was observed in the Gulf of Riga at low frequency (only $2-7 \%$ of morphologically analysed individuals), but analysis of DNA nucleotide barcoding of the same population did not confirm its presence. However, its presence in the eastern part of the Gulf of Finland has been confirmed by both morphological and molecular methods, where its abundance varied from $4 \%$ to $47 \%$ for females and from 2\% to 50\% for males of analysed Eurytemora individuals (Sukhikh et al., 2013). Therefore, the possible $E$. carolleeae invasion in the Gulf of Riga was suspected. Sukhikh et al. (2013) also expected the establishment of $E$. carolleeae in the Gulf of Riga in the nearest future based on "the Gause's principle (Gause, 1932) of inevitable displacement of one of the species competing for the same resource 
or niche" as suggested by Alekseev et al. (2009). Higher reproduction rates of the North-American Eurytemora (Beyrend-Dur et al., 2009; Pierson et al., 2016), as well as longer lifespan of adults (Beyrend-Dur et al., 2009) can potentially contribute to successful invasion and establishment of the non-indigenous Eurytemora in the Baltic Sea, which might endanger the native population of E. affinis.

"Trends in arrival of new non-indigenous species" is one of HELCOM Core indicators (Anonymous, 2015) with the main goal to minimise anthropogenic introduction of nonindigenous organisms to zero. The Good Environmental Status boundary for this indicator has been set to "no new introductions of non-indigenous species per assessment unit through human activities during a six-year assessment period" (Anonymous, 2015). Application of the indicator list of present non-indigenous species has to be updated regularly. Therefore, the aim of the present study was to reevaluate the presence of E. carolleeae in the Gulf of Riga five years after its first record in 2008 (Sukhikh et al., 2013).

\section{MATERIALS AND METHODS}

Study site. The Gulf of Riga is located in the eastern part of the brackish Baltic Sea. It is a relatively isolated basin with a northward salinity gradient. Salinity ranges between 0.5-2.0 psu in its southern areas where the largest freshwater discharge occurs, to $7.0 \mathrm{psu}$ in northeast regions, but generally, salinity varies from 5.0 to 6.5 psu (Berzinsh, 1995). These low salinities are favourable for the development of Eurytemora affinis (Devreker et al., 2009). Furthermore, the Gulf of Riga is a shallow waterbody with a mean depth of 26 meters; thus, the water temperature closely follows the seasonal cycle of air temperature, reaching a maximum of $17-20{ }^{\circ} \mathrm{C}$ in upper layers during summer and freezing temperatures in winter. Consequently, a seasonal thermal stratification occurs from May to August (Kotta et al., 2008).

Sampling and identification. Sampling was conducted in station 119 (Fig. 1) in May, August, and November 2013. The sampling station is located close to the Riga harbour, a hotspot of non-indigenous species arrival, as shipping is one of the main vectors responsible for species introduction in the Baltic Sea (Ojaveer et al., 2017).

One mesozooplankton sample was collected in each sampling event by means of vertical haul from bottom to top using a WP-2 plankton net with mesh size $100 \mu \mathrm{m}$ and opening $0.25 \mathrm{~m}^{2}$. The collected samples were preserved with $4 \%$ formaldehyde solution in seawater. In total, 75 females and 75 males of Eurytemora were randomly selected and studied, 25 individuals of each sex per sample. Morphological comparison between $E$. affinis and E. carolleeae was done using three indices following Sukhikh et al. (2013):

- for both sexes: Index 1 = length/width of the caudal rami (Fig. 2 A, B);

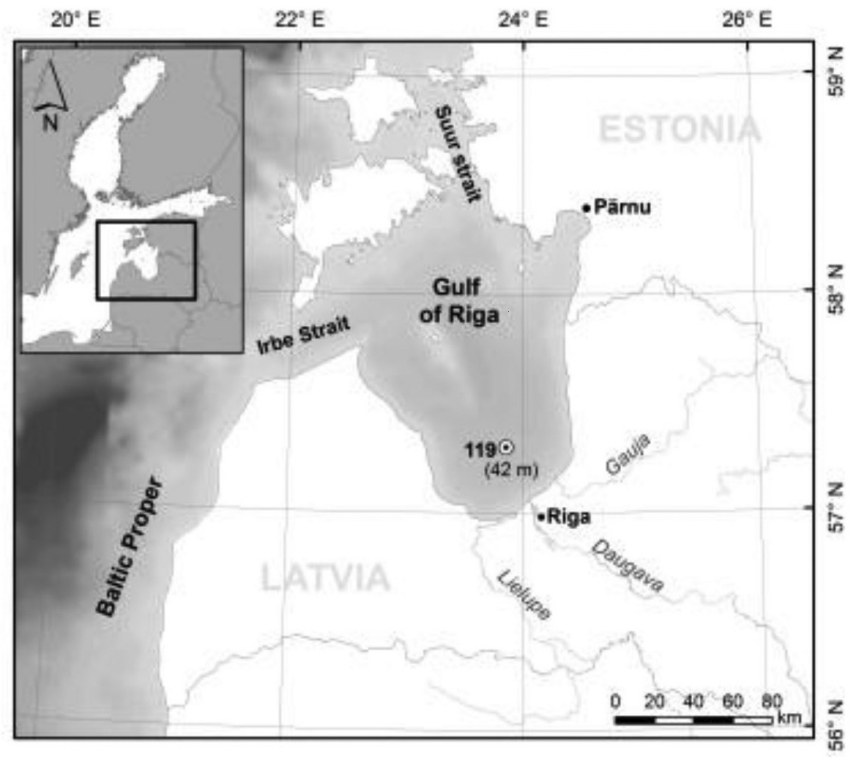

Fig. 1. Map of the study site. Sampling station 119 (N 57² $18^{\prime}$ E $\left.23^{\circ} 51^{\prime}\right)$ is marked with a white circle with small black dot in the middle. It is approximately 42 meters deep.
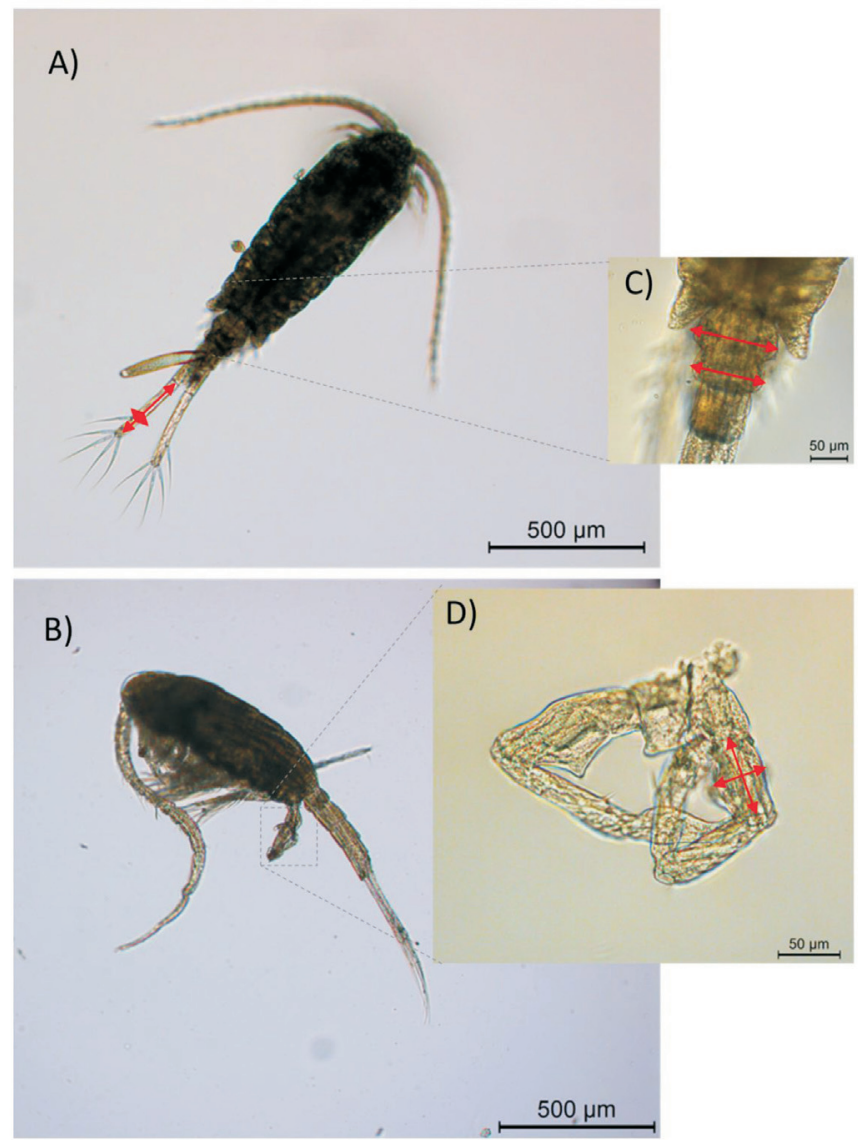

Fig. 2. Chosen morphometric indices for Eurytemora identification: A) adult Eurytemora female; red arrows indicate length/width of caudal rami (complementary Index 1, used for both sexes); B) adult Eurytemora male; C) female genital segment (Index 2); D) fifth pair of male swimming legs (Index 3). Red arrows indicate measured parameters.

- for females: Index 2 = anterior/posterior sides of the genital segment (Fig. 2 C); 
- for males: Index $3=$ length/width of the exopodite first segment in leg 5 (Fig. 2 B, D).

Firstly, photos of the morphological features needed for measurement of each parameter were taken using a compound microscope Leica DM4000 equipped with a built-in digital camera Leica DFC295 and Leica software LAS v4.1. Measurements were made with ImageJ@) software (Rasband, 1997-2015). The data were analysed based on the first description of E. carolleeae (Alekseev and Souissi, 2011) and the study of the new species pattern in the Baltic Sea region (Sukhikh et al., 2013).

According to previous studies (Alekseev and Souissi 2011; Sukhikh et al., 2013), the main difference between $E$. affinis and $E$. carolleeae females is Index 2, which is much higher (1.35) in E. carolleeae compared to the native E. affinis (Alekseev and Souissi, 2011). In contrast, Index 1 does not seem to be a good discriminator between both species in the Gulf of Riga; E. affinis females have average value of 7.59 for Index 1, compared to a value of 6.06 for E. carolleeae in Chesapeake Bay (Alekseev and Souissi, 2011). Based on the available literature, we set an indicative value of Index 1 for E. carolleeae less than 6.50 , but we treated it as a complementary parameter. Similarly for males, Index 1 was treated as a complementary parameter for E. carolleeae identification, because the caudal rami length/width ratio in E. affinis males from the Gulf of Riga and E. carolleeae males from the Chesapeake Bay overlaps even more than in females. In this case the indicative value of Index 1 was set to 9.50 . Index 3 was treated as a determinant index for $E$. carolleeae detection and values higher than 1.40 strongly indicating affiliation to E. carolleeae. However, the most unambiguous proof of $E$. carolleeae presence is when both 2 and 3 indices deviate from the set indicative values (Table 1).

Statistical analysis. Index 1 corresponded to a normal distribution. Index 2 and Index 3 were Box-Cox transformed (Wessa, 2015). The "Outlier Labelling Rule" (Hoaglin et al., 1986) was applied to detect statistically significant outliers. The independent samples T-test was used to compare indicator values between seasons The one-sample T-test, evaluated with 1000 bootstrap replicates, was used to compare measured values to indicative values to approve or disapprove affiliation to E. carolleeae (Table 1). Shapiro-Wilk test for Normality, T-test and bootstrapping analysis was carried out in IBM $^{(}$SPSS $^{\circledR}$ Statistics v20.

\section{RESULTS}

The results of morphological analysis indicated a low possibility of spread of the population of E. carolleeae in the Gulf of Riga (Fig. 3). In fact, only five females had a value of Index 2 higher than the set indicative value of 1.35 , and for these Index 1 ranged between 8.3 and 10.8, indicating affiliation to E. affinis. Fifteen males reached the indicative value of 1.4 for Index 3, and one of them was determined as a statistically significant outlier (Fig. 3). Another outlier
USED INDICATIVE VALUES FOR SPECIES DIFFERENTIATION IN THE GULF OF RIGA*

\begin{tabular}{l|c|c|c|c}
\hline \multirow{2}{*}{ Species } & \multicolumn{2}{c|}{ Females } & \multicolumn{2}{c}{ Males } \\
\cline { 2 - 5 } & Index 1 & Index 2 & Index 1 & Index 3 \\
\hline E. affinis & $>6.50$ & $<1.35$ & $>9.50$ & $<1.40$ \\
E. carolleeae & $<6.50$ & $>1.35$ & $<9.50$ & $>1.40$ \\
\hline
\end{tabular}

*Values based on Alekseev and Souissi, 2011; Sukhikh et al., 2013.

Index 1 (for both sexes) = length/width of the caudal rami; Index 2 (for females) $=$ width of anterior side/width of posterior side of the genital segment; Index 3 (for males) = length/width of the exopodite first segments in leg 5 (for more information about indices see Sukhikh et al., 2013). Index 1 was treated as a complementary index. Index 2 and Index 3 were treated as main indices. If both indices (for each sex) deviate from the set indicative values accordingly, then strong indication of affiliation to one or another species is suggested.
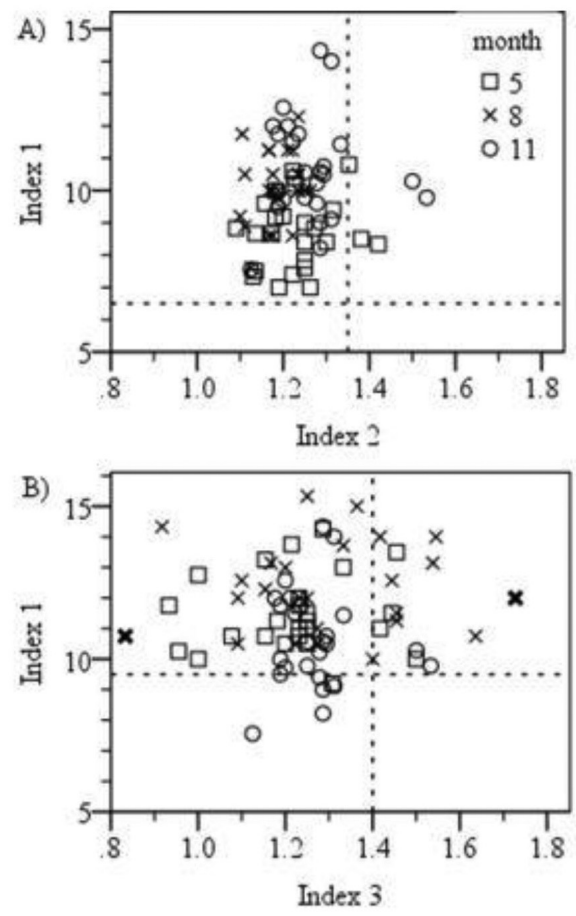

Fig. 3. Values of recommended indices (Sukhikh et al., 2013) for identification of Eurytemora sibling species (E. affinis and E. carrolleae): A) females and B) males. Index 1 (for both sexes) = length/width of the caudal rami; Index 2 (for females) = width of anterior side/width of posterior side of the genital segment; Index 3 (for males) = length/width of the exopodite first segments in leg 5 (for more information about indices see Sukhikh et al., 2013). Dotted lines show approximate border of indices between both species - upper left square corresponds to E. affinis indication; all other (but mostly two lower squares) - might correspond to E. carrolleeae indication (see Table 1). Bolded markers indicate statistically significant outliers ("Outlier Labeling Rule"; Hoaglin et al., 1986).

with a value just slightly above 0.8 was marked, but it was ignored in further analysis as it was well below the indicative value. However, considering the complementary Index 1 , none of those fifteen males reached the indicative value needed to confirm the presence of an E. carolleeae male in the Gulf of Riga.

The independent samples T-test (Table 2) showed statistically significant differences between seasons for Index 1 


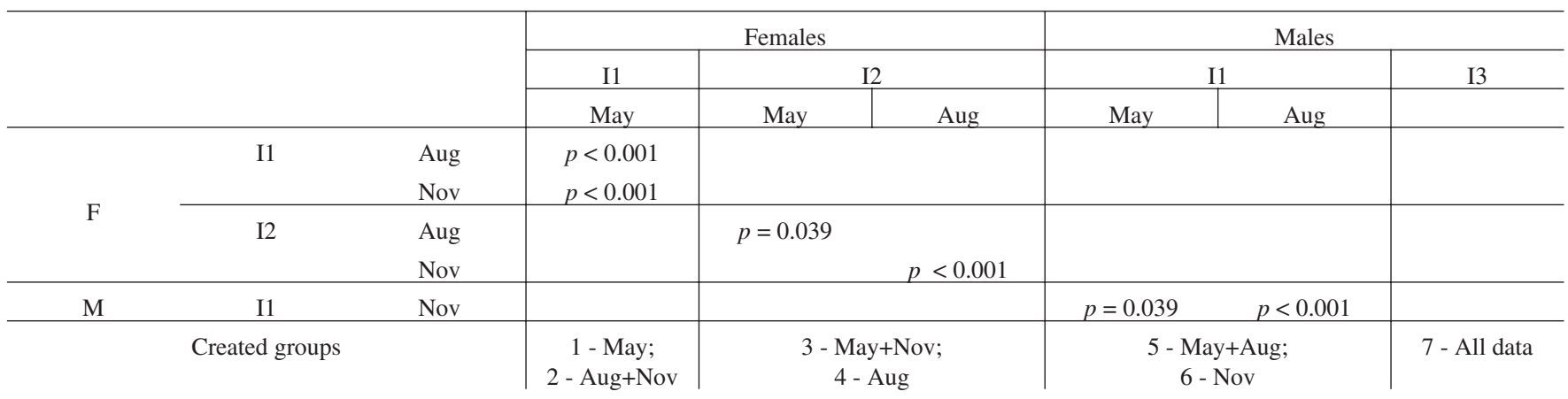

Only significantly different groups are shown. F - Females; M - Males; I1 - Index 1; I2 - Index 2; I3 - Index 3. Last row indicates which data was pooled for each indicator $(+)$, according to their similarity in a one-sample T-test (1-7 group No)

(for both males and females) and Index 2. Eurytemora females tended to have length/width ratio of the caudal rami (Index 1) significantly lower in May than in August and November, while the lowest values of Index 1 for Eurytemora males occurred in November. Significantly higher values of Index 2 occurred in August (Table 2). The data from seasons with non-significant differences were pooled (Table 2 last row) for comparison to target indicator values. All values of Index 3 across seasons were pooled due to non-significant variability among seasons. Again, the Index values differed significantly from the target indicator threshold values of all three indices $(p<0.001)$, reinforcing our conclusion about the low possibility of spread of $E$. carolleeae population in the Gulf of Riga.

\section{DISCUSSION}

Considering the high productivity of North American Eurytemora carolleeae in Chesapeake Bay (Pierson et al., 2016) and in the St. Lawrence estuary (Beyrend-Dur et al., 2009; Lloyd et al., 2013), its establishment in the Gulf of Riga is likely inevitable. Nevertheless, the E. carolleeae population has not settled and spread in the study site between 2008 and 2013, according to the results of present study. However, previous study sites were conducted in tidal zones (Beyrend-Dur et al., 2009; Lloyd et al., 2013; Pierson et al., 2016), which are not fully comparable to our sampling site located in the southern part of the non-tidal ecosystem of the Gulf of Riga. Indeed, the study site is an important parameter to consider, since copepod populations can differ in development between inshore and offshore waters, as demonstrated by Mouny and Dauvin (2002) for $E$. affinis in the Seine estuary. In addition, the sites where $E$. carolleeae presence was confirmed by both morphological and molecular analysis were located in coastal bays in the eastern part of the Gulf of Finland (Alekseev et al., 2009; Sukhikh et al., 2013) and this underlines the importance of the study site. The region studied in the Gulf of Finland was characterised by intensive maritime traffic and the highest ballast water discharges in the Baltic Sea (Anonymous,
2014), which might play a significant role in providing a constant and stable population of E. carolleeae.

The inter-annual variability in hydro-meteorological conditions can also affect Eurytemora abundance (Viitasalo et al., 1995). The year 2013 started with a harsh winter, in contrast with two consecutive mild winters of years 2007 and 2008 just before the first observation of E. carrolleeae in the Gulf of Riga. Furthermore, water temperature in spring 2008 was one of the highest since onset of observations (Latvian Institute of Aquatic Ecology, monitoring data, unpublished). These unique environmental conditions might have been favourable to the spread of E. carolleeae in that period. In addition, oceanic circulation can affect the spatial distribution of copepod species as demonstrated (St-Onge-Drouin et al., 2014) for two different E. affinis clades present in the St. Lawrence Estuary.

Finally, individual variability of local E. affinis should be considered as well. Size parameters of E. affinis showed high seasonal, inter-annual and spatial variability in prosome and urosome length and width in the Gulf of Riga, with standard deviation ranging from 5 to $16 \%$ of the mean for females, and 6 to $13 \%$ for males (Labuce et al., in prep.). Considerable seasonal fluctuation in dimensions of E. affinis individuals of the Gulf of Riga was also described for individual body mass of copepods (Line, 1983). A similar tendency was observed in measured dimensions of caudal rami for both male and female, which disputed the applicability of Index 1 in the Gulf of Riga. In addition, seasonal variation was observed in measurements of the genital segment (Index 2), which might be related to higher reproduction rates in higher temperatures (Gasparini et al., 1999). Moreover, improvement in precision of measurements can be obtained by analysing symmetrical traits on both sides of the body (Lajus et al., 2015). In our study only one side of the body was measured for symmetrical traits (only right caudal rami; Index 1), which might have increased measurement error for Index 1 values.

As a conclusion, we deduce that there is no evidence of persistent occurrence of a E. carolleeae population in the Gulf 
of Riga. However, inspection of coastal areas and ports should be conducted for verification, as well as more morphological indicators tested for applicability in the Gulf of Riga. Molecular analysis should also be carried out in further studies. Moreover, a regular monitoring program surveilling non-indigenous species is necessary to evaluate the presence of E. carolleeae and other non-native species in the study area.

\section{ACKNOWLEDGEMENTS}

This research was partly funded by Latvian National Research Programme 2014-2017 "The value and dynamic of Latvia's ecosystems under changing climate" (acronym EVIDEnT), and is a contribution to the French-Latvian project PHC OSMOSE.

\section{REFERENCES}

Alekseev, V. R., Abramso, N. I., Sukhikh, N. M. (2009). Introduction of sibling species to the ecosystem of the Baltic Sea. Doklady Biological Sciences, 429, 544-547.

Alekseev, V. R., Souissi, A. (2011). A new species within the Eurytemora affinis complex (Copepoda: Calanoida) from the Atlantic Coast of USA, with observations on eight morphologically different European populations. Zootaxa 2767, 41-56.

Anonymous (2013). Report of the ICES/HELCOM Working Group on Integrated Assessments of the Baltic Sea (WGIAB), 8-12 April 2013, Chioggia, Italy. ICES CM 2013/SSGRSP:05. 40 pp.

Anonymous (2014). HELCOM Guide to Alien Species and Ballast Water Management in the Baltic Sea. $40 \mathrm{pp}$.

Anonymous (2015). Trends in arrival of new non-indigenous species. HELCOM core indicator report. Available from:

http://www.helcom.fi/Core\%20Indicators/Trends\%20in\%20arrival\%20of $\% 20$ new $\% 20$ non-indigenous $\% 20$ species-HELCOM\%20core\%20indicato r\%20report\%202015-extended\%20version.pdf (accessed 14 February 2017).

Berzinsh, V. (1995). Hydrology. In: Ojaveer, E. (Ed.). Ecosystem of the Gulf of Riga between 1920 and 1990. Estonian Academy Publishers, Tallinn, pp. 7-31.

Beyrend-Dur, D., Souissi, S., Devreker, D., Winkler, G., Hwang, J. S. (2009). Life cycle traits of two transatlantic populations of Eurytemora affinis (Copepoda: Calanoida): Salinity effects. J. Plankton Res., 31, 713-728.

Croskery, P. (1978). The freshwater co-occurance of Eurytemora affinis (Copepoda: Calanoida) and Manayunkia speciosa (Annelida: Polychaeta): Possible relicts of a marine incursion. Hydrobiologia 59, 237-241.

Devreker, D., Souissi, S., Winkler, G., Forget-Leray, J., Leboulenger, F. (2009). Effects of salinity, temperature and individual variability on the reproduction of Eurytemora affinis (Copepoda; Calanoida) from the Seine estuary: A laboratory study. J. Exper. Marine Biol. Ecol., 368, 113-123.

Gasparini, S., Castel, J., Irigoien, X. (1999). Impact of suspended particulate matter on egg production of the estuarine copepod, Eurytemora affinis. J. Marine Syst., 22, 195-205.

Gause, G. F. (1932). Experimental studies on the struggle for existence. $J$. Exper. Biol., 9, 389-402.

Hoaglin, D. C., Iglewicz, B., Tukey, J. W. (1986). Performance of some resistant rules for outlier labeling. J. Amer. Statist. Assoc., 81, 991-999.

Jurgensone, I., Carstensen, J., Ikauniece, A., Kalveka, B. (2011). Long-term changes and controlling factors of phytoplankton community in the Gulf of Riga (Baltic Sea). Estuaries and Coasts, 34, 1205-1219.
Kornilovs, G., Möllmann, C., Sidrevics, L., Berzinsh, V. (2004). Fish predation modified climate-induced long-term trends of mesozooplankton in a semi-enclosed coastal gulf. ICES CM 2004/L:13, 1-26.

Kotta, J., Lauringson, V., Martin, G., Simm, M., Kotta, I., Herkül, K., Ojaveer, H. (2008). Gulf of Riga and Pärnu Bay. In: Schiewer, U. (Ed.). Ecology of Baltic Coastal Waters. Springer-Verlag, Berlin, pp. 217-243.

Lajus, D., Sukhikh, N., Alekseev, V. (2015). Cryptic or pseudocryptic: Can morphological methods inform copepod taxonomy? An analysis of publications and case study of the Eurytemora affinis species complex. Ecology and Evolution, 5 (12), 2374-2385.

Lee, C. E. (2000). Global phylogeography of a cryptic copepod species complex and reproductive isolation between genetically proximate "populations". Evolution 54, 2014-2027.

Lee, C. E., Frost, B. W. (2002). Morphological stasis in the Eurytemora affinis species complex (Copepoda: Temoridae). Hydrobiologia, 480, 111-128.

Line, R. (1983). Description of individual body mass changes for key zooplankton species of the Gulf of Riga Eurytemora hirundoides and Acartia bifilosa [Лине, Р. Я. Характеристика изменений массы тела основных видов зоопланктона Рижского залива Eurytemora hirundoides и Acartia bifilosa]. Rybokhozyaistvennye issledovaniya $\mathrm{v}$ basseine Baltiyskogo morya [Рыбохозяйственные исследования в бассейне Балтийского моря], 18, 10-16 (in Russian).

Livdāne, L., Putnis, I., Rubene, G., Elferts, D., Ikauniece, A. (2016). Baltic herring prey selectively on older copepodites of Eurytemora affinis and Limnocalanus macrurus in the Gulf of Riga. Oceanologia 58, 46-53.

Lloyd, S., Elliott, D. T., Roman, M. R. (2013). Egg production by the copepod, Eurytemora affinis, in Chesapeake Bay turbidity maximum regions. J. Plankton Res., 35, 299-308.

Mouny, P., Dauvin, J. C. (2002). Environmental control of mesozooplankton community in the Seine estuary (English Channel). Oceanologica Acta, 25, $13-22$

Ojaveer, E., Lumberg, A., Ojaveer, H. (1998). Highlights of zooplankton dynamics in Estonian waters (Baltic Sea). ICES J. Marine Sci., 55, 748-755.

Ojaveer, H., Olenin, S., Narščius, A., Florin, A.-B., Ezhova, E., Gollasch, S., Jensen, K. R., Lehtiniemi, M., Minchin, D., Normant-Saremba, M., Strāḳe, S. (2017). Dynamics of biological invasions and pathways over time: A case study of a temperate coastal sea. Biol. Invasions, 19 (3), 799-813.

Pierson, J. J., Kimmel, D. G., Roman, M. R. (2016). Temperature impacts on Eurytemora carolleeae size and vital rates in the upper Chesapeake Bay in winter. Estuaries and Coasts, 39 (4), 1122-1132.

Rasband, W. S. (1997-2015). ImageJ@. U. S. National Institutes of Health, Bethesda, Maryland, USA. Available from: http://imagej.nih.gov/ij/ (accessed 02.03.2015).

Sukhikh, N., Alekseev, V. R. (2013). Eurytemora caspica sp. nov. from the Caspian Sea - one more new species within the E. affinis complex (Copepoda: Calanoida: Temoridae). Proc. Zool. Inst. RAS, 317, 85-100.

Sukhikh, N., Souissi, A., Souissi, S., Alekseev, V. R. (2013). Invasion of Eurytemora sibling species (Copepoda: Temoridae) from north America into the Baltic Sea and European Atlantic coast estuaries. J. Nat. Hist., 47, $753-767$.

Sukhikh, N., Souissi, A, Souissi, S., Winkler, G., Castric, V., Holl, A. C., Alekseev, V. (2016). Genetic and morphological heterogeneity among populations of Eurytemora affinis (Crustacea: Copepoda: Temoridae) in European waters.Comptes Rendus Biologies, 339, 197-206.

St-Onge-Drouin S., Winkler G., Dumais J. F., Senneville S. (2014). Hydrodynamics and spatial separation between two clades of a copepod species complex. J. Mar. Syst., 129, 334-342.

Telesh, I., Heerkloss, R. (2004). Atlas of Estuarine Zooplankton of the Southern and Eastern Baltic Sea. Part II: Crustacea. Verlag Dr. Kovač, Hamburg. $118 \mathrm{pp}$. 
Viitasalo, M., Vuorinen, I., Saesmaa, S. (1995). Mesozooplankton dynamics in the northern Baltic Sea: implications of variations in hydrography and climate. J. Plankton Res., 17, 1857-1878.

Wessa, P. (2015). Box-Cox Normality Plot (v1.1.11) in Free Statistics Software (v1.1.23-r7). Office for Research Development and Education. Avail- able from: http://wessa.net/rwasp_boxcoxnorm.wasp/ (accessed 12 February 2016).

Winkler, G., Souissi, S., Poux, C., Castric, V. (2011). Genetic heterogeneity among Eurytemora affinis populations in Western Europe. Mar. Biol., 158, 1841-1856.

Received 27 March 2017

Accepted in the final form 18 November 2017

Published online 6 July 2018

\section{SVEŠZEMJU EURYTEMORA CAROLLEEAE POPULĀCIJAS KLĀTBŪTNES IZVĒRTĒŠANA RĪGAS LĪCĪ PIECUS GADUS PĒC TĀS PIRMĀ KONSTATĒ ŠANAS GADİJUMA}

Kalanoīdais kopepods Eurytemora affinis ir atslēgas suga Rīgas līča ekosistēmā, bet 2008. gada vasarā konstatēta arī svešzemju sugas Eurytemora carolleeae klātbūtne Baltijas jūrā, ieskaitot Rīgas līci. Eurytemora carolleeae ir novērtēta kā fizioloğiski plastiska suga, un nesenos pētījumos tiek norādīts uz tās iespējamo invāziju Baltijas jūrā. Šajā pētījumā tika izvērtēta svešzemju E. carolleeae populācijas klātbūtne Rīgas līča dienvidu dạ̣ā, proti, reǵionā vistuvāk Rīgas ostai, kas darbojas kā viens no galvenajiem avotiem jaunu sugu ienākšanā. Eurytemora pieaugušo indivīdu taksonomiskā piederība tika izvērtēta paraugos, kas ievākti 2013. gada maijāa augustā un novembrī, izmantojot trīs morfoloǵiskus indikatorus. Tomēr, neraugoties uz efektīvākiem reprodukcijas rādītajiem un garāku pieaugušo indivīdu dzīvildzi, šì pētījuma rezultāti liecināja, ka E. carolleeae nav spējusi veiksmīgi iedzīvoties Rīgas līcī, un tāpēc pagaidām nav apdraudējums vietējai E. affinis populācijai. 